\title{
BOLSHEVIK ACTIVITY AMONGST THE WORKING WOMEN OF PETROGRAD IN $1917^{1}$
}

This article attempts to examine the activity of the Bolshevik Party amongst the working women of Petrograd in 1917, and in particular the conflicting Bolshevik attitudes towards work amongst women. The study has been limited to Petrograd, because the situation there, while not typical, was of vital importance. The Petrograd Committee was a major policy-making body within the party, and a wide spectrum of attitudes towards work amongst women existed at this time within the Petrograd party. The major primary sources used for this article were the 1917 editions of Pravda, and 13 issues of Rabotnitsa, from May 1917 to January $1918 .^{2}$

\section{Background}

Marx and Engels wrote very little of direct bearing on the woman question. The first of their followers to treat it as a specific issue was August Bebel. In 1879 Bebel published a book entitled Die Frau und der Sozialismus. ${ }^{3}$ This provided a theoretical basis for a Marxist party's attitude towards the woman question. The next step was taken by Clara Zetkin, who was the first Marxist to appreciate the need for a practical approach to the question. Zetkin realised that the growing bourgeois feminist movement

1 All dates cited refer to this year, unless otherwise specified. Dates throughout are according to the old (Julian) calendar, which was 13 days behind the Western (Gregorian) calendar. I have used the conventionally accepted name of Petrograd throughout, including when referring to the local Bolshevik committee, called by the Bolsheviks at that time Peterburgskii komitet RSDRP(b).

2 Rabotnitsa. Ezhenedel'nyi zhurnal. Organ Tsentral'nogo Komiteta RSDRP(b) (Petrograd). II-i god izdaniya. Seven issues had been published in 1914.

${ }^{3}$ First published in Zurich, 1879. First English edition: Woman in the Past, Present and Future (London, 1885). Several different editions were published in Russian, the first in London in 1895 under the title Zhenshchina nastoyashchego, proshedshego i budushchego vremeni. 
was succeeding in appealing across class divides to working women, thereby threatening the unity of the proletariat. For this reason she concluded that a Marxist party should adopt two methods of work with relation to women. First, they should attack the feminist claim that all women have more in common with each other than with men from their own class, and they should stress that feminism would lead to division and separatism in the workers' movement. Second, they should undertake special party work amongst women in order to counter the feminists' influence and raise the class-consciousness of working women. Zetkin's implacable hostility to the feminists gradually changed the "orthodox" attitude of Social Democracy towards them from one of tolerance to one of bitter opposition. However, her views created a paradox, for her efforts to stimulate the party into devoting special attention to work amongst women led some members to accuse her of the very crime she was trying to combat - feminism. ${ }^{4}$

The Bolsheviks were greatly influenced by the work of both Bebel and Zetkin, and as the following account of their work during 1917 attempts to show, the paradoxical element in Zetkin's approach was inherited by them, and it created ambiguity and division within the party where work amongst women was concerned. The first major work on women by a Russian Marxist was Alexandra Kollontai's Sotsial'nye osnovy zhenskogo voprosa, published in 1909.5 The main theme of it, and of many of Kollontai's other writings before 1917, was a reiteration of the view that as there was no separate woman question, there should be no separate women's movement.

The followers of historical materialism deny the existence of a special woman question separate from the general social question of our day. [...] woman can become truly free and equal only in a world reorganised along new social and productive lines. ${ }^{6}$

4 Cf. R. Stites, The Women's Liberation Movement in Russia (Princeton, 1978), pp. 236-38.

5 A. M. Kollontai, Sotsial'nye osnovy zhenskogo voprosa (St Petersburg, 1909). The original introduction is reproduced in id., Izbrannye stat'i i rechi (Moscow, 1972), pp. 61-81. The only earlier work on women by a Russian Marxist is an anonymous agitational pamphlet by N. K. Krupskaya, Zhenshchina-rabotnitsa (Geneva, 1901). This pamphlet did not make a theoretical contribution to the debate on a Marxist approach to the woman question, but its publication was the first acknowledgement from the RSDRP of the need for literature aimed specifically at women. An original copy of the pamphlet and a microfilm copy of Sotsial'nye osnovy are held by the International Institute of Social History, Amsterdam.

6 Kollontai, Sotsial'nye osnovy, p. 4. 
But despite her frequent anti-feminist pronouncements, Kollontai, like Zetkin, suffered from her fellow Marxists' deep suspicions of feminism. Most Bolsheviks understood the anti-feminist position to include opposition to any kind of separate organisation inside or outside the party. Kollontai however, again like Zetkin, believed that the peculiarly backward and doubly oppressed nature of the woman's situation, combined with the success of the feminists, necessitated special efforts on the part of the Bolsheviks to draw women into political activity - even to the extent of creating specific party organisations to deal with them. 1917 was to prove a valuable testing time for these opposing views, and the eventual outcome, the setting up of the zhenotdely, or women's bureaux, was viewed by many as a victory for the Zetkinist approach. ${ }^{7}$

The only attempt of any note that the Bolsheviks made before 1917 to arouse women to political action was in 1914, before Kollontai joined the party. A group of women Bolsheviks including N. K. Krupskaya, Inessa Armand, A. I. Elizarova (Ul'yanova), L. N. Stal', K. N. Samoilova and P. F. Kudelli started publication of a journal, Rabotnitsa, aimed specifically at women. However, only a few issues were published before it was shut down by the Tsarist police, and very little more was done in this direction until a few Bolshevik women, this time with the addition of Kollontai, seized their opportunity in 1917.8

By February 1917 the role of women had acquired a new significance. The First World War resulted in a substantial increase in the numbers of women employed in industry. By early 1917 one third of Petrograd's factory workers were women. ${ }^{9}$ All branches of industry were affected. In the metal-working industry, where before the war female labour had been extremely limited, by 1917 women constituted one fifth of the workforce. Almost half the workers in the chemical industry were women, and in industries such as food, textiles and tailoring the proportion was as high as two thirds of the total workforce. At the beginning of the year there were altogether 129,800 women workers in the factories of Petrograd. ${ }^{10}$

Finally, if any further proof was needed that the working women of Petrograd were an important source of mass support, the unprecedented events of February spoke for themselves. As one witness of those events,

"For more information on the zhenotdely, see C. E. Hayden, "The Zhenotdel and the Bolshevik Party", and R. Stites, "Zhenotdel, Bolshevism and Russian Women, 1917-1930", both in: Russian History, III (1976), pp. 150-93.

${ }^{8}$ For pre-1917 Bolshevik work amongst women, see A. Bobroff, "The Bolsheviks and Working Women, 1905-20", in: Soviet Studies, XXVI (1974), pp. 540-65.

9 Istoriya rabochikh Leningrada (Leningrad, 1972), I, p. 467.

10 Ibid., II, p. 13. 
Pitirim Sorokin, wrote in his diary, "The Russian Revolution was begun by hungry women and children demanding bread and herrings. [...] Only later did they, together with workmen and politicians, become ambitious to wreck that mighty edifice - the Russian Autocracy." 11 It is true that the women's primary demands were basic - reflecting their very basic and urgent needs -, but it is no coincidence that the day they chose to demonstrate was February 23, International Women's Day. Moreover, the February Revolution may have got rid of the Tsar, it may even have given women the vote, but it had not alleviated the women's misery, or dealt with the desperate need that had driven them on to the streets. The Provisional Government had not brought an end to the food crisis or the war. The revolutionary mood of the women was not therefore dispelled after February. The female masses of Petrograd remained an important source of support for any party which could gain their allegiance. At least some members of the Bolshevik Party recognised this and were determined to ensure that the Bolsheviks would win the battle for that support.

\section{First steps}

After the February Revolution the Bolshevik Party, together with all the other Russian political parties, was legalized. Pravda immediately resumed publication. The second issue, which came out on March 7, carried a lead article which praised enthusiastically the revolutionary activities of the women of Moscow and Petrograd.

February 23 - Women's Day - was the day of the Russian Revolution and the first day of the Third International. A great day for the workers of the world.

Glory to Woman! Glory to the International!

Glory to the great Russian Revolution! ${ }^{12}$

However, the Bolsheviks hardly had cause to praise their own activities during the February period. They behaved warily in the critical days before the outbreak of industrial unrest in Petrograd, warning workers against isolated strikes, believing that the time was not yet ripe for action. ${ }^{13}$

11 P. A. Sorokin, Leaves from a Russian Diary, enlarged ed. (Boston, Massachusetts 1950), p. 3.

12 "Velikii den", in: Pravda, No 2 (7 March). The article had been published as a separate leaflet by the Central Commitee of the Bolshevik Party some five days before. See Revolyutsionnoe dvizhenie $v$ Rossii posle sverzheniya samoderzhaviya [Velikaya Oktyabr'skaya sotsialisticheskaya revolyutsiya, Dokumenty i materialy] (Moscow, 1957), p. 8 .

${ }_{13}$ G. Katkov, Russia 1917. The February Revolution (London, 1967), pp. 252-53. 
A. G. Shlyapnikov reported that the Bolsheviks could not even produce a leaflet for Women's Day because the then illegal Pravda press had broken down. He also describes how some Bolshevik women had to persuade the reluctant Vyborg party raikom (district committee) to hold a meeting on February 23 on the theme "The War, High Prices and the Situation of the Working Woman". ${ }^{14}$

On the eve of Women's Day, V. Kayurov from the Petrograd Bolshevik Committee addressed a women's meeting. He called on the women to "refrain from isolated actions and to act exclusively according to the directives of the party committee". ${ }^{15}$ Kayurov later described his reaction on learning that some of the women from the textile factories had gone on strike.

I was extremely indignant about the behaviour of the strikers: firstly because they had blatantly ignored the decision of the district committee of the party, and secondly because I myself had appealed to the women workers that very night for self-control and discipline, and now suddenly they were on strike. ${ }^{16}$

Faced with the fact of the strike, the Bolsheviks were forced to react. According to Kayurov it was only with reluctance that they decided to support the women strikers and place themselves at the head of the strikes and demonstrations. Evidently the Bolsheviks did not play a decisive role in the organisation of Women's Day activities, but were in fact carried along almost unwillingly by the revolutionary wave which swept the city. However, as if to make amends for this lack of action during February, the Bolsheviks were quick to take advantage of their new-found freedom in March.

A meeting of the Executive Committee of the Petrograd Committee on March 10 gave Vera Slutskaya the task of organising work amongst women. ${ }^{17}$ Three days later, at an enlarged session of the Executive Committee, Slutskaya explained the need for such work and she suggested that a Bureau of Women Workers be set up under the auspices of the Petrograd Committee for this purpose, that the journal Rabotnitsa should resume publication and that special leaflets and popular pamphlets directed at women be printed. The meeting resolved that Slutskaya should draw up a

14 A. G. Shlyapnikov, Semnadtsatyi god. Kniga pervaya, 2nd ed. (Moscow, 1923), pp. 60-61.

15 V. Kayurov, "Shest' dnei fevral'skoi revolyutsii", in: Proletarskaya Revolyutsiya, 1923, No 1 (13), p. 158.

16 Ibid.

17 Pervyi legal'nyi Peterburgskii komitet Bol'shevikov v 1917 g. (Moscow, 1927), p. 33;

Revolyutsionnoe dvizhenie v Rossii posle sverzheniya samoderzhaviya, op. cit., p. 55. 
plan for the organisation of a bureau, and that Pravda would carry an announcement about it. ${ }^{18}$

At a meeting of the Petrograd Committee on March 15 Slutskaya's detailed proposals were read. It was repeatedly stressed that the bureau would carry out "purely agitational work", that "women workers will in general organise themselves in the workers' political and trade-union organisations", that "no independent women's organisations whatsoever will be created", and that "all work will be carried out in full accordance with the decisions of the Petrograd Committee". Yet despite these assurances, one of the delegates at the meeting still felt it necessary to express his opposition to the formation of a special Bolshevik women's organisation. It was immediately pointed out that this was not in fact what was being proposed. The meeting resolved to set up a bureau for conducting agitational work amongst women and to take steps towards restarting publication of Rabotnitsa, but it was decided to leave examination of Slutskaya's proposals in detail until a later date. ${ }^{19}$ At a further meeting of the Executive Committee on March 24 the position on organisation was clarified. In factories women were to enter the ordinary factory committees with men and not to form their own, except in cases where all the workers were women, then women's factory committees could be established. Finally, if women's clubs should spring up spontaneously, the Bolsheviks would not hinder them, but they would warn that such women's clubs "are not in the interest of the unity of the working class as a whole". ${ }^{20}$

The pages of Pravda in the first month after the February Revolution reflect both the increasing political activity of women and the growing acceptance by the Bolsheviks of the need to extend their influence amongst the women workers of Petrograd. Almost every edition carries notices and reports of women's meetings, articles aimed at women or information about the Bolsheviks' plans to publish Rabotnitsa and establish women's bureaux. These Pravda issues indicate that Bolshevik support was fairly strong a mongst domestic servants, laundresses, inn and restaurant workers and textile workers, and in certain regions of Petrograd, in particular the Vyborg, Moskovskii and Vasileostrovskii districts. The meetings generally called on women to organise themselves in trade unions, and their demands normally included points of particular concern to women such as full equal rights, insurance for women workers and maternity protection, as well as the usual demands for an eight-hour working day, a democratic

18 Pervyi legal'nyi Peterburgskii komitet Bol'shevikov, op. cit. p. 40.

19 Ibid., pp. 45-46.

20 Ibid., p. 69. 
republic and land redistribution. ${ }^{21}$ These meetings were by no means insignificant - reports frequently boast of an attendance of around one thousand. ${ }^{22}$ This figure usually included male workers as well, but as these particular industries employed a primarily female workforce, the men would normally have been very much in the minority. One report of a meeting of domestic servants relates how the appointed meeting place could not hold all those wanting to attend, so the meeting spilled over into the street with the result that the police ordered the crowd to disperse. It ends with a plea that somewhere more suitable be found for future meetings. ${ }^{23}$

The first weeks after the February Revolution thus saw an unprecedented increase in the number of women organising themselves to make political and economic demands. But the Bolsheviks were not alone in seeking to harness this new force for their own ends. Izvestiya reported that on March 19, under the leadership of the Russian League for Women's Equality, thirty-five thousand women marched to the Tauride Palace with placards demanding democratic voting rights and calling for "War until Victory". Although only a minority of the demonstrators were working women, this was nevertheless an impressive show of strength on the part of the feminists. ${ }^{24}$ The Bolsheviks would have to step up their efforts if they were to combat successfully the influence of the feminists and their other opponents. At this time Pravda alone was waging the struggle to draw women into the Bolshevik Party. ${ }^{25}$ A new impetus was needed from the Bolshevik leadership. On March 19 Pravda reported the return of Kollontai to Petrograd. Subsequent issues show that Kollontai's arrival had provided that impetus. ${ }^{26}$

21 For examples of women's meetings' demands, see Pravda, Nos 4 (9 March) and 8 (14 March).

22 For attendance figures, see ibid., Nos 6 (11 March), 9 (15 March) and 12 (18 March).

${ }^{23}$ Ibid., No 7 (12 March).

24 Izvestiya, 21 March. There is some disagreement over the numbers on this demonstration. Izvestiya, the only available primary source to provide an actual figure, reported that 35,000 attended. However, N. D. Karpetskaya, Rabotnitsy i Velikii Oktyabr' (Leningrad, 1974), p. 41, who also cites this source, gives a figure of 3,500. Stites, The Women's Liberation Movement, op. cit., p. 292, cites a figure of "some 40,000".

25 Apart from "Velikii den" (see note 12), no leaflets issued by the Bolsheviks during March were aimed specitically at women. Listovki Petrogradskikh bol'shevikov 1917-20 (Leningrad, 1957).

26 A. M. Kollontai, "Rabotnitsy i uchreditel'noe sobranie", in: Pravda, No 14 (21 March); id., "Nash pamyatnik bortsam za svobodu", ibid., No 16 (23 March); ibid., No 18 (26 March), article by L. Stal'. April editions of Pravda show an increase in the volume of articles aimed at women. 


\section{Anti-feminist or feminist?}

By chance Kollontai arrived back in Petrograd on the eve of the feminists' demonstration at the Tauride Palace. Thus it was that on her first day in revolutionary Russia Kollontai's attention was immediately drawn to the problem which had so long occupied her energies - the question of party work amongst women, and opposition to the Russian feminists. Pravda carried no report of the demonstration, but Kollontai later described her own experiences at the palace. Although a few hundred working women attended the demonstration, most of the women were from the upper classes, and when Kollontai tried to address them from the steps of the palace she met with a hostile reception. She was dragged off the steps and some soldiers even threatened to bayonet her. ${ }^{27}$

Undeterred, Kollontai immediately resumed her attack on the feminists in the next issue of Pravda. In an article entitled "Working Women and the Constituent Assembly" she warned women not to expect to be given their rights without a struggle.

Only the bourgeois baryn'ki from the League of Equality can talk about having to obtain Mr Rodzyanko's "promise" to let women into the Constituent Assembly, and then everything will be sewn up! [...] The Constituent Assembly is not a club, the keys to which lie in Mr Rodzyanko's pocket; and neither he nor even the whole Provisional Government may or may not allow this or that section of the population to enter it. ${ }^{28}$

Kollontai argued that if admission to the Assembly depended on Rodzyanko, he would welcome the female supporters of the bourgeois parties, but would slam the door in the faces of working women. But Kollontai's criticisms were not only directed at the bourgeois feminists. She also attacked the view prevalent among working men, possibly even among male party members, that if women were given the vote they would spoil their new freedom by their stupidity - they might even want to bring back the Tsar'-batyushka! She argued that to deprive women of their political rights would on the contrary only weaken the revolutionary army of the proletariat. Kollontai urged the Bolsheviks to carry out at once widespread work amongst working women to ensure that their participation in the Constituent Assembly would mean greater support for the Bolshevik Party in that body.

The next edition of Pravda announced the first meeting of the women's bureau which had been set up in accordance with Slutskaya's proposals.

27 Kollontai, Rabotnitsa za god revolyutsii (Moscow, 1918), pp. 8-10; id., "Avtobiograficheskii ocherk", in: Proletarskaya Revolyutsiya, No 3 (1921), pp. 261-302.

${ }_{28}$ Kollontai, "Rabotnitsy", loc. cit. 
Pravda had already carried notice of the formation of the bureau and of the intended publication of Rabotnitsa, and donations had begun to arrive for the Rabotnitsa fund. However, during the period from late March to mid April Pravda made only two more announcements of women's-bureau meetings, and only two party raikoms are recorded as having set up their own district women's bureaux, the Okhtinskii ${ }^{29}$ and Porokhovskoi districts. In the latter case Lyudmila Stal', who had worked on the 1914 Rabotnitsa, addressed the meeting which resolved to set up a bureau and she no doubt played a major part in persuading the meeting to take that decision..$^{30}$ Only two days after this meeting the newly formed bureau held a public meeting on the May-1st celebrations, the war and the International, which was attended by around 2,000 people. ${ }^{31}$ However, this did not mark the beginning of a thriving women's organisation within the party based on a network of district bureaux. On the contrary, after the report of the Porokhovskoi meeting there is not a single further mention of women's bureaux in Pravda.

The reason for the failure of the attempt to put into practice Slutskaya's proposal is not clear. No formal resolution to close the bureaux was passed. It appears that the bureaux simply folded up of their own accord. But this was not for lack of need of an organisational centre, nor for lack of support from women workers as shown by the successful Porokhovskoi meeting. Stal', in a short article published in 1922, gave the following explanation for the failure of Slutskaya's plan.

After the February Revolution attempts were made to set in motion organisation of work amongst the female proletariat following the example of German Social Democracy. But these attempts were broken up by the resistance of district party workers. They thought that the conducting of special work amongst women reeked of feminism and that it was pointless to divide party work between the sexes. The attempts of the Petrograd Committee to organise an all-Petrograd centre for work amongst proletarian women therefore failed. Rabotnitsa [...] became the sole organisational centre for such work. ${ }^{32}$

As Stal' indicates, the failure of the bureaux does not mark the collapse of Bolshevik work amongst women. On the contrary, the group of women Bolsheviks who formed the new editorial board of Rabotnitsa became

${ }^{29}$ Okhtinskii khimicheskii kombinat (Leningrad, 1965), p. 166, cited in Karpetskaya, Rabotnitsy; op. cit., p. 42.

30 Pravda, No 34 (16 April).

31 Ibid.

32 L. Stal', "Rabotnitsa v oktyabre”, in: Proletarskaya Revolyutsiya, No 10(1922), p. 299. 
the centre of an enthusiastic agitational and organisational campaign. Although it is true that this work amongst women encountered opposition from some members of the party, Stal"s argument that this was the cause of the failure of the bureaux does not supply the whole answer. If this were so, why was there no, or little, interference with the work of the Rabotnitsa group? The bureau had after all been designated a centre for agitation, not for separate organisation, and during its short existence it hardly had time to accomplish its limited objective, far less to overstep the mark. Yet when Rabotnitsa was revived it quickly became far more active than the bureau had been in that controversial area of organisation, but it was allowed to survive and flourish. The answer to the mysterious disappearance of the bureaux lies not so much in that they encountered resistance, as in the fact they were supplanted by a more effective organisational centre, which at the same time was not in fact a "separate organisation" within the party, and so could escape charges of "feminist deviation". Those members of the party who were really eager to work among the female masses of Petrograd were immediately drawn into the work on Rabotnitsa. Thus with the talents and energies of Kollontai, Stal', Samoilova, Kudelli, K. I. Nikolaeva, Elizarova and V. M. Velichkina (Bonch-Bruevich) - that is with the most ardent advocates of work amongst women - collected in the editorial board of Rabotnitsa it was only natural that it quickly fulfilled the proposed role of the bureau and made it redundant. Moreover, as the editors of Rabotnitsa the women enjoyed greater freedom than they would have done as the organisers of the bureau, whose activities were closely scrutinized by the Petrograd Committee.

Meanwhile, as the editorial board of Rabotnitsa prepared for publication the debate within the party on the question of special work amongst women continued. An article in Pravda on April 7 by N. Glebov reiterated the call for unity, stressing the idea that "purely women's organisations" are for bourgeois women who demand only equal rights, not for proletarian women who share common needs and aims with proletarian men. ${ }^{33}$ It is no coincidence that this article by Glebov - the only article on the woman question by a male Bolshevik to appear in Pravda during 1917 - reaffirmed the traditional hostility of the party to "separate women's organisations". However, the debate should not be seen only in terms of a struggle between the men and the women in the party. Kollontai's later writings show that she often came into conflict with other Bolshevik women as well as men over her views. For example, Samoilova was a strong

33 N. Glebov, "Zhenshchina v rabochem dvizhenii", in: Pravda, No 26 (7 April). 
opponent of separate organisation for women, as Kollontai noted in a collection of writings published in memory of Samoilova after her premature death from typhus in 1921. Kollontai's remarks are important, not only because they show Samoilova's wariness towards "separatism" in the party, but also because they help explain why Rabotnitsa enjoyed greater success as an organisational centre than did the women's bureau.

As late as the spring of 1917 Konkordiya Nikolaevna [Samoilova] found superfluous the formation of an apparatus in the party for work amongst women. On the other hand she warmly welcomed the rebirth of Rabotnitsa as an ideological centre [. . .]. Comrade Samoilova would not tolerate anything that smacked of feminism and she regarded with great caution any organisational scheme which in her opinion might introduce "division according to sex" into the proletariat. But when she saw that we had little strength for agitation amongst women and that the female masses themselves provide the best agitators, she formed a group [of women agitators] on her own initiative and without prior permission, and used it to conduct systematic work. ${ }^{34}$

Thus, although Samoilova was opposed in theory to any sort of separate organisation, she willingly became involved in the work of Rabotnitsa and the practicalities of that work forced her to accept that some separate organisation was to a certain extent unavoidable.

Another woman Bolshevik who did not approve of Kollontai's views was Krupskaya. Although she had written the first Russian Marxist pamphlet on women and had worked on the 1914 Rabotnitsa, in 1917 she showed little interest in the problem of work among women. ${ }^{35}$ Like Samoilova she was suspicious of anything which smelt of feminism. In her memoirs Kollontai recounts an incident involving Krupskaya which illustrates the differences between their views on how work amongst women should be conducted. Kollontai was concerned that she had had to neglect work amongst women because the party kept her occupied with other tasks, and "only snatches of time and energy were left for working women and soldatki". ${ }^{6}$ Yet despite all the other demands on her Kollontai had not in

34 Kollontai, "Tvorcheskoe v rabote t. Samoilovoi", in: Revolyutsionnaya deyatel'nost' Konkordii Nikolaevny Samoilovoi. Sbornik vospominanii (Moscow, 1922), pp. 8-9.

35 Krupskaya's main area of work in 1917 was with youth. She wrote articles for Pravda on child labour, youth organisation and education. (See, for example, Nos 34 and 65 (7 June).) She worked in the Vyborg district, developing a network of schools, reading rooms and nurseries. Cf. R. H. McNeal, Bride of the Revolution (London, 1973), p. 175. Soviet accounts attempt to associate her with the 1917 Rabotnitsa, but in fact she wrote no articles for it, nor did she speak at meetings organised by the Rabotnitsa editorial board. 36 Kollontai, Iz moei zhizni i raboty (Moscow, 1974), p. 267. Soldatki: soldiers' wives, sometimes also used to refer to soldiers' mothers and daughters. 
fact neglected the women of Petrograd. She had been working almost single-handedly amongst the soldatki to improve their lot, ${ }^{37}$ and also to counter the influence of the "female liberal-defencists", who were making great efforts to organise the soldatki in a union under their control.

Kollontai describes how, shortly after Lenin's return to Petrograd, she was walking with him and Krupskaya from Kirochnaya to the Tauride Palace when she decided to broach the subject of the soldatki. When Lenin showed some interest in her efforts to win them over to the Bolsheviks, Kollontai plunged into her idea that the party should form a commission or bureau for work amongst women. Krupskaya immediately objected that work amongst the soldatki should enter the general channel of party work - that there was no need for a "special organisation". Kollontai retorted:

"What do you mean, a 'special organisation'? I'm talking about the need to create an organ within the party and responsible to it - a bureau or what have you which could deal with this work. I'm not talking at all of a separate women's organisation."

I grew heated, arguing not so much with Nadezhda Konstantinova as with all the comrades who don't want to understand the necessity for such a method of work. ${ }^{38}$

Lenin intervened in the argument with a conciliatory proposal. He suggested that Kollontai should draw up plans and discuss them with other women Bolsheviks. Meanwhile she should carry on working with the soldatki, but "on her own responsibility". Kollontai took up Lenin's suggestion and she, Nikolaeva and Federova drew up a plan of work. ${ }^{39}$ However, even Inessa Armand, Kollontai's old friend and collaborator, was not happy about the project. ${ }^{40}$ Kollontai agreed that Z. Lilina, Stal' and Armand should devise a new scheme which would be submitted in the

37 Before the war the soldatka had ranked almost as low as the prostitute. When the war turned millions of peasants and working women into soldatki, the social stigma was forgotten, and soldatki were issued a monthly allowance of 7 to 9 roubles, but by the spring of 1917 this had been virtually wiped out by inflation. Cf. Stites, The Women's Liberation Movement, p. 305.

${ }^{38}$ Kollontai, Iz moei zhizni i raboty, op. cit., p. 268. No precise date is given for this conversation, but it almost certainly took place in mid April. Obviously by this time any bureaux inaugurated by Slutskaya's plan had either folded, or they were not, in Kollontai's view, fulfilling their role.

39 The proposals in this plan were subsequently accepted by the party in 1919, when they became the basis for the zhenotdely. Kollontai, "Avtobiograficheskii ocherk", loc. cit., p. 297.

40 Armand was active at this time amongst the working women of Moscow, where she published Zhizn' Rabotnitsy, a sister paper to Rabotnitsa, which had a circulation of 15,000. Shestoi s"ezd RSDRP (bol'shevikov). Protokoly (Moscow, 1958), p. 158. 
form of a resolution at the forthcoming conference. ${ }^{41}$ The next day Inessa Armand read through the new proposals to Kollontai, adding that she was not satisfied with them but had found herself in the minority. Kollontai could hardly believe her ears: "The proposal was so composed that the outcome was a sweeping censure of any separate work amongst women." 42

Kollontai made one more attempt to raise the question of a special party apparatus for work amongst women at the Petrograd party conference at the end of April, but once again she received no support. ${ }^{43}$ The minutes of the meeting show that there was not even any discussion on the question. Sergei Bagdat'ev from the Petrograd district proposed that the Petrograd Committee organize a department for women's agitation. However, the chairman insisted that this question be withdrawn as there were no women present with voting rights. After a protest from Bagdat'ev the question was withdrawn. ${ }^{44}$ Despite these defeats in the area of organisation, Kollontai continued her activities amongst the working women and soldatki, and on the practical level she was more successful.

\section{Soldatki and laundresses}

On April 11 15,000 soldatki marched to the Tauride Palace to ask the Soviet to support their demand for a twenty-rouble allowance. Kollontai was the only member of the Soviet to show support for them. They were met by F. I. Dan, the Menshevik chairman of the Soviet, who told them that the exchequer was empty, and that instead of demanding more money they

41 According to Kollontai, Iz moei zhizni i raboty, pp. 269, 401 (editorial note), the conference at which the resolution was to be put forward was the First Petrograd Conference of Working Women, which took place in November. However, as the proposals were drawn up in April, long before the decision to hold a women's conference was made, it seems likely that they were intended for one of the two party conferences held towards the end of April.

42 Kollontai, Iz moei zhizni i raboty, p. 269.

43 Id., "Avtobiograficheskii ocherk", p. 297.

44 Sedmaya (aprel'skaya) vserossiiskaya konferentsiya RSDRP(b), Petrogradskaya obshchegorodskaya konferentsiya RSDRP(b) (Moscow, 1958), pp. 27-34. This incident appears to have caused some confusion. Alix Holt, in her otherwise accurate account in Selected Writings of Alexandra Kollontay (London, 1977), p. 114, states the minutes are from the Seventh all-Russian Congress, when in fact they are from the second session of the Petrograd City Conference ( 15 April). A mistake in interpretation is made by B. E. Clements, Bolshevik Feminist. The Life of Aleksandra Kollontai (Bloomington, Indiana, 1980), p. 110. Clements interprets the chairman's reply to Bagdat'ev 'zdes' net zhenshchin s reshayushchim golosom" as meaning that the proposal would be withdrawn because women in Russia did not as yet have the vote. In fact the chairman is referring to the fact that there were no women delegates with voting rights present. (The Provisional Government had granted the women the vote in its Declaration of 3 March.) 
should be demanding an end to the war. Kollontai could not restrain her anger. She asked to be allowed to address the women in the name of the Bolshevik Party. Dan refused, and seeing that it was useless to argue with him Kollontai held an impromptu meeting at the palace gates. She talked to the soldatki about the war, high prices, their meagre allowances and the revolutionary struggle to bring an end to the war. She urged them to organise their own special section of soldatki and send delegates to the Soviet. ${ }^{45}$

Shortly afterwards a meeting of soldat $k i$ from the Central District Trusteeship ${ }^{46}$ demanded the immediate transfer of the Trusteeship's funds to the Soviet and the abolition of the Trusteeship. The meeting supported the Bolshevik representative, who proposed the election of delegates from the Central District soldatki to the Soviet. There were 21 trusteeships altogether in Petrograd, and similar meetings were held in each region. In mid April an all-city meeting of soldatki at the Tauride Palace formed a city committee of soldatki which consisted of 35 soldatki and a few members of the Executive Committee of the Soviet, including Kollontai. The committee decided to take into its own hands the welfare of soldiers' families, and to renew the demand for an allowance of twenty roubles. They also raised Bolshevik political demands for an end to the war and power to the Soviets.

At the end of May a Conference of Working Women from Vyborg side, organised by the Bolsheviks, passed a resolution from representatives of the Vyborg soldatki which demanded a twenty-rouble allowance; that officers' wives should receive the same allowance as ordinary soldat $i$; that "our breadwinners, exhausted by three years of war should be replaced [at the front] by members of the bourgeoisie and others hiding from the war"; that "this robbers' war which brings profit only to the capitalists should be ended immediately". The resolution concluded with the demand "All power to the Soviets". In June the committee of soldat $i$ formed a Union of Soldiers' Wives which conducted agitational work. ${ }^{47}$

The masses of embittered, starving soldatki, organised in Union reading groups, provided fertile ground for Bolshevik anti-war propaganda. Kollontai, aided by a couple of other women Bolsheviks, Federova and

45 Kollontai, "Demonstratsiya soldatok", in: Pravda, No 30 (12 April).

46 The Trusteeship (popechitel'stvo) was the body charged with the administering of allowances and rations to soldiers' families.

47 The whole of this account of Bolshevik activity amongst the soldatki following the demonstration of 11 April is taken from Dvoretskaya, "Soyuz Soldatok", in: Zhenshchiny goroda Lenina (Leningrad, 1963), pp. 77-81. 
Devyatkina, made important headway amongst them, while at the same time counter-acting the attempts of the feminists to use the trusteeships to persuade the soldatki to accept ever greater self-sacrifices in the name of patriotism. Moreover, the disaffected mood of the soldatki and their growing sympathy for Bolshevik demands spread to their husbands at the front through an organised campaign of letters and articles to papers such as Soldatskaya Pravda. When Kerensky announced the new offensive at the end of June, the Bolshevik-led Union of Soldiers' Wives was well placed to exploit the reaction against it.

During May Bolshevik influence amongst the working women of Petrograd was further enhanced by their support for another of the most backward and neglected sections of the female population, the laundresses. The city's seven to eight thousand laundresses worked up to fourteen hours a day in the most appalling conditions. ${ }^{48}$ They had begun to organise themselves after the February Revolution, advertising their meetings in Pravda, and by the beginning of May 3,000 of the city's washerwomen had joined the newly formed Union of Laundresses. ${ }^{49}$ The laundresses decided to strike after their demands for an eight-hour day and a minimum wage of four roubles a day were rejected by the laundry owners. ${ }^{50}$ The strike began on May l and spread quickly, so that by the following day three quarters of the city's laundresses were on strike. ${ }^{51}$

Once again the efforts of just a few Bolshevik women, Goncharskaya, who headed the laundresses' union, Novik-Kondrat'eva and Sakharova, who led the strike committee, and of course Kollontai, who publicised the laundresses' cause in the Soviet, and in Pravda and Rabotnitsa, galvanized the Bolsheviks into giving full, active support to the laundresses. Kollontai launched the campaign with two articles in consecutive editions of Pravda entitled "On Our Firing Line", 52 in which she described the working conditions in the industry, outlined the laundresses' demands and called upon workers to meet the threat of closure from the owners with the demand for municipalization of the laundries. She described the efforts of the employers to break the strike by forming their own strike-breakers' union, and by more violent methods. Kollontai stressed that the women laundresses were fighting not just for themselves, but in the interests of the whole working class, that their victory would be a fresh victory for the

\footnotetext{
48 Kollontai, "Na nashei linii ognya", in: Pravda, No 51 (7 May); id., "Pervaya zabastovka v Svobodnoi Rossii", in: Rabotnitsa, No 3 (20 May), p. 6.

49 Kollontai, "Pervaya zabastovka", loc. cit.

50 Kollontai, "Na nashei linii ognya", loc, cit.

51 "Stachka prachek", in: Pravda, No 51.

52 Kollontai, "Na nashei linii ognya"; Pravda, No 52 (9 May).
} 
whole proletariat. She urged that both moral and material support be given to the laundresses, and that the Soviet should declare its solidarity with the women, as they were fighting to force the employers to accede to demands which had been passed by the Soviet.

Kollontai's appeals were successful. On May 8, in response to her report on the plight of the laundresses the Executive Committee of the Soviet agreed to grant the women strikers 5,000 roubles. ${ }^{53}$ Pravda devoted space daily throughout the month-long strike to reports, appeals for funds and messages of support from workers in other industries. Donations flowed into the strike fund from trade unions, district soviets, factory committees and sailors' committees. The messages of solidarity which streamed into the Pravda offices urged the laundresses to maintain their steadfast struggle against the employers and strike-breakers, and reiterated Kollontai's call "Your victory is our victory".

Finally on May 31 Pravda announced that the strike had ended successfully, the employers had accepted the women's demands. But the victory was only partial. When the laundresses returned to work, the employers frequently reneged on their promises. Women who had taken an active part in the strike were not taken back on, and many laundries were closed down. It was not until after the October Revolution that the laundresses' demands were fully implemented. ${ }^{54}$ Nevertheless the laundresses' strike was significant. It showed those who thought it a waste of time to try to organise women that even the most backward sections of the female proletariat could conduct an organised strike with some hope of success, if they could win the support of workers in other industries. It was an important propaganda and agitational victory for the Bolsheviks, and more particularly for Kollontai and the other Bolshevik women, whose efforts had brought the strike to the attention of the party. On the other hand it was also significant that the Bolsheviks did not automatically support the laundresses' strike (despite the fact that it was the first strike for

53 According to Holt, Selected Writings of Alexandra Kollontay, op. cit., p. 115, Kollontai reported to the "Executive Committee of Social Revolutionaries and Social Democrats", but I have interpreted the title "Ispolnitel'nyi komitet SR i SD" as cited in Karpetskaya, Rabotnitsy, op. cit., p. 53, as referring to the "Ispolnitel'nyi komitet Soveta Rabochikh i Soldatskikh Deputatov". Kollontai herself, "Avtobiograficheskii ocherk”, p. 296, states that she took the matter to the Soviet and the Executive Committee. Unfortunately I have not been able to find a primary source which refers to the meeting of 8 May.

54 A. T. Barulina, "Rabota Petrogradskoi i Moskovskoi partorganizatsii sredi zhenshchin-rabotnits (mart-oktyabr' 1917 g.)", in: V bor'be za pobedu Oktyabrya: Sbornik statei (Moscow, 1957), pp. 197-98. 
economic demands since February), but had to be prodded into action by Kollontai.

\section{Rabotnitsa}

On May 11 Pravda announced the publication of the long-awaited first edition of Rabotnitsa. Almost exactly two months had passed since the Petrograd Committee had taken the decision to resurrect it. From the rather scant information that can be gleaned from the pages of Pravda during this period, ${ }^{55}$ it can be seen that the slow progress was due to practical difficulties rather than to any lack of enthusiasm amongst those involved in the work on Rabotnitsa. It took some time for the women who were to form the core of the editorial staff to return from various parts of Europe, and once they had assembled in Petrograd they found themselves short of both funds and material. Pravda carried frequent requests for articles and reports for Rabotnitsa, and it was not until May 4 that the Central Committee of the party agreed to give Stal' 2,000 roubles for the journal. ${ }^{56}$ Finally, work on Rabotnitsa could occupy only a small proportion of the women's time. As we have seen, Kollontai felt that only snatches of her time and energy could be devoted to working women and soldatki, ${ }^{57}$ and in these snatches she not only worked on Rabotnitsa, but also helped organise the soldatki and laundresses, and both she and Stal' wrote articles for Pravda on women, and frequently addressed women's meetings.

The first edition of Rabotnitsa, a double issue, was published on May 10. Contributions to it were mainly from members of the editorial board, although Lilina and B. Breslav also provided material. All the articles discussed matters of particular concern to working women. These included the history of the journal Rabotnitsa, the role of the Russian working woman in the workers' movement, the gains of the Russian Revolution for women and the tasks lying ahead, and the struggle for peace. Questions such as the eight-hour working day, maternity leave, child labour and working conditions were also discussed. Finally the issue contained poetry, notices of women's meetings, advertisements for other Bolshevik publi-

55 Notices in Pravda of Rabotnitsa meetings supply us with our only information about the work leading up to the publication of the journal, as the minutes of these meetings are unavailable. Cf. Karpetskaya, Rabotnitsy, p. 7: "Unfortunately, material describing the activities of the editorial collective of the journal has not been preserved in the Central Party Archives." Neither has available memoir material proved useful in this respect.

56 V. V. Anikeev, Deyatel'nost' TsK RSDRP(b) v 1917 godu (Moscow, 1969), p. 103. A further 2,000 roubles was given to Rabotnitsa by the Central Committee in July. Ibid., p. 206.

57 See above, p. 139. 
cations - in particular a leaflet produced by the Rabotnitsa board, "High Prices and the War", and requests for financial contributions and articles for future issues, and lastly a plea for help with the distribution of the journal. ${ }^{58}$

Rabotnitsa was well received, the thirteen issues published from May 1917 to January 1918 each sold around 50,000 copies. ${ }^{59}$ It had been well publicised in advance, both in Pravda and through the editorial board's campaign of active propaganda and agitation at factory meetings. For example A. I. Rodionova, a worker at the Vasileostrovskii trampark, describes how the workers there were told about Rabotnitsa and decided to support it even before the first issue was published.

In April at a general meeting of Vasileostrovskii trampark workers, Comrade Leonov raised the question of help for the editorial board of Rabotnitsa. Despite the grave material situation of the workers the opinion was unanimous: we would each give the journal three days' pay. ${ }^{60}$

Rodionova's subsequent experiences were typical of the activist style of work of the Rabotnitsa board. She was given the task of taking the 800 roubles they had collected to the Rabotnitsa office and was quickly drawn into the work on the journal. She developed links between the editors and the trampark workers. She distributed copies of the journal and information about meetings organised by the editorial board, and arranged for members of the collective to address meetings of the trampark workers. Eventually she was persuaded to write articles herself for the journal. ${ }^{61}$

The publication of Rabotnitsa was thus an integral part of a much wider agitational campaign, which gathered momentum during May and June with the introduction of public meetings organised by the editorial board, and the formation of a school of agitators attached to the journal. The editorial staff agreed to organise the school and work out a programme for it at a meeting on May 4. Lectures were to take place weekly, starting with one on the subject of the elections to the regional dumas. ${ }^{62}$ It seems fairly obvious from Kollontai's later writing that the initiative for this school of

58 Rabotnitsa, No 1-2 (10 May).

59 Kollontai, Rabotnitsa za god revolyutsii, op. cit., p. 12. An alternative figure of 40,000 is given in Shestoi s"ezd RSDRP(b), op. cit., p. 147. C. Porter, Alexandra Kollontai (London, 1980), p. 255, accounts for this discrepancy with the information that the original print-run of 40,000 was increased to 50,000 because of the demand. Unfortunately, Porter does not cite her source.

${ }^{60}$ A. I. Rodionova, "Semnadtsatyi god", in: Zhenshchiny goroda Lenina, op. cit., p. 90.

${ }^{61}$ Id., "Vash korrespondent", in: Vsegda s vami: Sbornik posvyashchennyi 50-letiyu zhurnala "Rabotnitsa" (Moscow, 1964), p. 103.

62 Pravda, No 50 (6 May). 
agitators came from Samoilova. ${ }^{63}$ The members of the school formed groups in the factories which helped with the distribution of Rabotnitsa and the organisation of meetings and lectures. Later members of these groups themselves became agitators among the women workers, and finally Rabotnitsa correspondents. ${ }^{64}$

From mid May onwards the Rabotnitsa group developed an intensive programme of public meetings. On May 15 Lilina, Stal' and Nikolaeva together addressed a women's meeting, ${ }^{65}$ and this inaugurated the pattern of popular meetings addressed by various members of the editorial board. On May 28 Stal', Kudelli and Kollontai spoke at a meeting on the subject of organisation of women. ${ }^{66}$ On June 11 the first of a number of huge public meetings on the theme "The War and High Prices" was held in the Cinizelli Circus. Around 10,000 attended, and the crowds overflowed on to the streets, where a second meeting was held in the open air. As well as speeches from the women on the editorial board, there were also guest speakers from the Swedish and Norwegian Social Democratic Parties' women's sections and, for the first time at a Rabotnitsa meeting, two male Bolsheviks, A. V. Lunacharsky and P. V. Dashkevich, addressed the meeting. ${ }^{67}$ A resolution of protest against "the monstrous high prices - the heavy burden weighing down the poor - and their true cause, the imperialists' world war" was passed. ${ }^{68}$ This meeting was followed by another one on the same theme held at the Patronnyi factory on June 25, which was attended by 5,000 workers, ${ }^{69}$ and a further one four days later on the organisation of working women which was held in the Cirque Moderne. ${ }^{70}$

By the end of June both the journal, six editions of which had already been published, and the women who comprised the editorial board of Rabotnitsa had become an established feature of political life in the capital. The success and popularity they enjoyed was due in part to the strong links they had forged with the factories through the use of agitators' groups, but in the main it was due to the fact that both the journal itself and the meetings concentrated on the twin evils which were making life a misery for working women - the war and high prices. The Provisional Govern-

6.3 See above, p. 139.

64 Karpetskaya, Rabotnitsy, p. 48.

65 Pravda, No 56 (13 May).

66 Ibid., No 66 (26 May).

67 Ibid., No 80 (13 June).

68 Ibid., No 81 (14 June).

69 Ibid., No 92 (27 June).

70 Ibid., No 94 (29 June). 
ment appeared to be doing nothing to solve the problem of the everlengthening bread queues, or to bring an end to the war. The end of June saw a general increase in support for the Bolsheviks, which was reflected in their representation at the First All-Russian Congress of Soviets, and a high-point in the campaign to attract the allegiance of working women was reached with the acceptance of Kollontai's paper on the protection of female labour, equal pay and the need to attract more women into the trade-union movement at the first legal All-Russian Congress of Trade Unions in late June. ${ }^{71}$

\section{Reaction and recovery}

The steady growth of Bolshevik influence from February to June was brought to an abrupt halt after the abortive July uprising. During the weeks of reaction which followed support for the Bolsheviks reached a very low ebb. All aspects of political work became more difficult, and work amongst women suffered particularly. The papers which replaced Pravda after its press had been wrecked gave women's interests far less coverage than Pravda had done. ${ }^{72}$ However, work amongst women was by no means totally neglected. The women on the editorial board minus Kollontai, who had been arrested, managed to maintain publication of Rabotnitsa, and for a while it was in fact the only legal organ of the Bolshevik Party. ${ }^{73}$ Soviet sources proudly recall that the first edition of Rabotnitsa after the July crisis carried Lenin's article "Three Crises". ${ }^{74}$ In fact it is a sad comment on the party's attitude towards work amongst women that the Pravda press had to be wrecked before an article by a leading male Bolshevik could grace the pages of Rabotnitsa. Attempts were made to confiscate that particular edition of the journal, but the women workers outwitted the Junkers who came to search the premises, and it was successfully produced and distributed. ${ }^{75}$

The difficulties encountered in publishing Pravda and Rabotnitsa were by no means the only problems which faced the Bolsheviks in July. The campaign against them was particularly effective amongst working women

71 N. Sibiriakova [K. N. Samoilova], "Zhenskii trud i zadachi prof. soyuzov", in: Rabotnitsa, No 7 (19 July).

${ }^{72}$ The papers which replaced Pravda from 6 July to 26 October were published under the names Listok Pravdy, Rabochii i Soldat, Proletarii, Rabochii and Rabochii Put'.

73 Karpetskaya, Rabotnitsy, p. 82.

${ }^{74}$ See, for example, Zhenshchiny goroda Lenina, p. 94; Vsegda s vami, op. cit., p. 128; Zhenshchiny $v$ revolyutsii (Moscow, 1959), p. 119.

${ }^{75} \mathrm{~K}$. Nikolaeva, "Slovo k molodym rabotnitsam", in: Zhenshchiny $\mathrm{v}$ revolyutsii, pp. 119-20. 
- the most "backward stratum" of the population. As Samoilova later wrote,

in the broad masses of working women the February Revolution had aroused only an upsurge in the revolutionary mood, it had not forged a firm class-consciousness, and thus such working women sometimes lost heart on the difficult, thorny path of revolution. [...] vacillation occurred particularly during the July days. ${ }^{76}$

Bolshevik women often received hostile treatment from their workmates during this period. At the Patronnyi factory a group of women workers attempted to throw a Bolshevik woman from the first floor ${ }^{77}$ At the Trubochnyi factory the women, believing the rumours that the Bolsheviks were German spies, planned to throw a Bolshevik who worked with them, A. Arbuzova, into a fire ${ }^{78} \mathrm{E}$. Tarasova, a Bolshevik from the Novyi Promet factory, had organised her fellow workers in a first-aid brigade. Yet when she arrived for work on July 5 , she had sharp aluminium screws thrown at her. The girls from her brigade broke down and cried when they saw blood on her face. They told Tarasova that the Mensheviks had set them against her, and put their newly acquired medical skills to good use ${ }^{79}$ This period also saw a fall in the number of working women in the party. Samoilova recalled that women were often taken in by the stories spread in the bread queues about the Bolsheviks, and they threw away their membership cards and struck their names off the party lists. ${ }^{80} \mathrm{~A}$ whole month passed without a Rabotnitsa meeting, and when one was eventually arranged for July 30 , it attracted only 700 people. ${ }^{81}$ However, by the end of July the worst was over and the tide was about to turn once more.

With the failure of the June offensive mass desertions from the front continued apace. The economic situation was growing more desperate and the Provisional Government was showing itself to be incapable of dealing with the mounting disorder. Women workers suffered particularly from the increased unemployment and falling wages of this period. ${ }^{82}$ The Bolsheviks benefited from this situation and the general resurgence of support

${ }^{76}$ K. Samoilova, Rabotnitsy v rossiiskoi revolyutsii (Moscow, 1920), p. 7.

77 A. Borisov, Fevral'skaya i Oktyabr'skaya revolyutsii i rabotnitsa (Moscow, 1926), p. 19, cited in Karpetskaya, Rabotnitsy, p. 81.

$78 \mathrm{~V}$ boyakh. Sbornik vospominanii posvyashchennyi geroicheskoi bor'be vasileostrovtsev za 15 let (Leningrad, 1932), p. 31, cited ibid.

${ }^{79}$ E. Tarasova, "Pod znamenem Bol'shevikov", in: Zhenshchiny v revolyutsii, pp. 136-37.

${ }^{80}$ Samoilova, Rabotnitsy v rossiiskoi revolyutsii, op. cit., p. 7.

81 Rabochii i Soldat, No 10 (3 August).

82 Kollontai, Rabotnitsa za god revolyutsii, p. 14. 
for them was reflected in improved support for them at meetings of women workers. On August 1 Rabochii $i$ Soldat carried a report of a meeting of domestic servants in the Cirque Moderne. The meeting was attended by 1,000 domestic workers who protested against the slanderous attacks on the Bolsheviks and the imprisonment of their leaders. In particular they demanded the immediate release of Kollontai, who, they declared, "had promoted the development of our union". ${ }^{83}$ A mass meeting was held in the Cirque Moderne on August 22 to protest at the continued imprisonment of Kollontai, whose health had seriously declined.$^{84} \mathrm{~A}$ week later another Rabotnitsa meeting, attended by 5,000 people, demanded the immediate freeing of all Bolsheviks still under arrest, and the free return to Russia of Lenin and Zinoviev. ${ }^{85}$ At another meeting in the Cirque Moderne on September 25 Kollontai, who had recently been freed from house arrest, was carried out of the meeting shoulder-high to the loud applause of the crowds. ${ }^{86}$

According to Samoilova, the political instability and lack of classconsciousness amongst working women revealed during the July days forced the Bolsheviks to pay greater attention to work amongst women. She wrote that for this reason special bureaux or sections began to be formed, attached to party organisations, for the conducting of more intensive work among the female proletariat, and to attract working women into the general proletarian organisations ${ }^{87}$ Although such a decision was made in August by the Moscow party ${ }^{88}$ there is no evidence to suggest that the Petrograd Committee resurrected the bureau idea. Its only contribution to the task of attracting women into the party during the summer was the publication of a leaflet calling on women workers to vote for the Bolsheviks in the elections to the Petrograd Central Duma ${ }^{89}$ However, Kollontai later wrote that she and Sverdlov decided in September to form a bureau for work amongst women in time for the electoral campaign for the Constituent Assembly. ${ }^{90}$ Kollontai can only have been referring to the Initiative Group of Women Workers which the party agreed to set up in early October, and whose main task was to prepare for a Petrograd Confer-

83 Rabochii i Soldat, No 8 (1 August).

84 Rabotnitsa, No 9 (1 September), p. 12

85 Ibid., pp. 11-12.

86 Rabochii Put', No 22 (28 September).

87 Samoilova, Rabotnitsy $v$ rossiiskoi revolyutsii, p. 7.

88 Velikaya oktyabr'skaya sotsialisticheskaya revolyutsiya. Revolyutsionnoe dvizhenie $v$ Rossii v avguste (Moscow, 1959), pp. 48-50.

89 Listovki Petrogradskikh bol'shevikov, op. cit., pp. 69-70.

90 Kollontai, "Avtobiograficheskii ocherk", p. 299. 
ence of Working Women to be held in October as part of the Bolshevik campaign for the Constituent Assembly elections. ${ }^{91}$

\section{Revolution and after}

During early October work amongst women reached a pitch of activity reminiscent of that earlier peak in June. On October 1 Kollontai, Kudelli and Samoilova addressed a meeting in the Cirque Moderne on the Constituent Assembly. ${ }^{92}$ Kollontai also published at least two leaflets on the same subject, ${ }^{93}$ and she and Samoilova wrote articles for Rabochii Put' and Rabotnits $a^{94}$. The first meeting of the Initiative Group took place on October 6. The group, which consisted of 19 women from various factories, party organisations and the Rabotnitsa board, first heard reports from the localities. The delegates heard that the Narvskii-district party had been particularly active in the area of work amongst women, and had decided to organise agitators' courses to train working women in agitational skills. It was reported that in some factories women had joined the Red Guard. However, even in those organisations where relatively large numbers of women workers were represented, women rarely took an active and lively part in the organisation. The meeting agreed that the most urgent task was to raise the consciousness of women workers, to build up their confidence in their own strength. It was noted that Rabotnitsa had far higher circulation figures than the Menshevik paper for women, Golos Rabotnitsy. Many women were not even aware of the existence of the latter journal. The meeting unanimously agreed to arrange a Petrograd Conference of Working Women.

The tasks of this conference would be to carry out agitational work amongst the broad masses of working women, with the aim of preparing them for the elections to the Constituent Assembly, and to attract them into the party. The Initiative Group split into three sections for the organisational, agitational and propaganda preparations for the conference. It was decided that another meeting should be arranged for the near future, and representatives of workers' organisations not yet participating in the Initiative Group and a member of the Petrograd Committee would be invited to attend. Finally, a number of meetings would be arranged in connection with the conference, agitators' courses would be organised, and

91 Ibid.

${ }_{92}$ Rabotnitsa, No 11 ( 18 October), p. 14.

${ }^{93}$ Rabotnitsy i uchreditel'noe sobranie and $\mathrm{K}$ rabotnitse-izbiratel'nitse.

${ }^{94}$ Kollontai, "Kak nado rabotnitsam gotovit'sya $\mathrm{k}$ uchreditel'nomu sobraniyu?", in: Rabochii Put', No 36 (14 October); Samoilova, "Uchreditel'noe sobranie i rabotnitsy", in: Rabotnitsa, No 11 (18 October). 
leaflets and brochures distributed to publicise it. ${ }^{95}$ On October 10 the Third Petrograd Conference of the RSDRP(b) called for the earliest possible convocation of the Conference of Working Women, and agreed to conduct elections of delegates from the factories and party raikoms and to form agitational committees. ${ }^{96}$ On October 14 the second meeting of the Initiative Group took place. It was proposed that the conference should be held between October 27 and November 1. The agenda would be the following: a lecture on the tasks of the conference; reports from the floor; speeches on the Constituent Assembly and the working woman, protection and insurance for women workers, the Constituent Assembly and the bourgeois-feminist parties, socialism and the working woman, and finally organisational questions. Proposed speakers were Nikolaeva, Prokhorova, E. Solin, Samoilova, Kudelli, Lilina and Kollontai. ${ }^{97}$

On October 21 Kollontai wrote an article for Rabochii Put' on the conference and the party raikoms. From the tone of this article it is evident that Kollontai felt that the party organisations needed to be prodded into giving their active support to the conference. She stressed that the conference would draw women into the Bolshevik Party, adding to their support in the elections to the Constituent Assembly:

in this grave, historic hour, as the struggle for power is developing in Russia between the bourgeoisie and revolutionary democracy, the level of consciousness and organisation of working women may play a decisive part on one side or the other.

For this reason our Bolshevik Party must treat with all seriousness the preparations for the first conference of working women. ${ }^{98}$

On October 22 the Rabotnitsa editorial board together with the Union of Laundresses held another meeting in the Cirque Moderne on the Constituent Assembly. ${ }^{99}$ Altogether during the period leading up to the conference the Initiative Group organised seventy meetings, and they published numerous leaflets on both the Constituent Assembly and the forthcoming conference. ${ }^{100}$ Preparations for the opening of the conference were going smoothly when they were suddenly interrupted by the Bolsheviks' armed uprising on the night of October 25-26. In the heat of the

95 Kollontai, "Pervye shagi k sozyvu konferentsii rabotnits", in: Rabochii Put', No 32 (10 October).

96 Ibid., No 35 (13 October).

97 Ibid., No 38 ( 17 October).

98 Kollontai, "Konferentsiya rabotnits i partiinye raiony", ibid., No 42 (21 October).

99 Ibid.

100 L. Stal', Pechat' i zhenskoe kommunisticheskoe dvizhenie (Moscow, 1927), p. 37 , cited in Karpetskaya, Rabotnitsy, pp. 103, 105. See also Listovki Petrogradskikh bol'shevikov, pp. 98-100, and Kollontai's leaflets cited in note 93. 
revolution Kollontai somehow found time to write a brief article in Pravda, explaining that the conference had been postponed until early in November.

Stick to your revolutionary posts, women workers! [ . . ] all our strength, all our energies, all our thoughts must be given to the work of strengthening the power of revolutionary democracy, the power of the Soviets [ . . ]. The place of working-class women in these great days of the first proletarian revolution is amongst the courageous fighters for proletarian ideals. ${ }^{101}$

Women did indeed find their places "amongst the courageous fighters". Shortly after the February Revolution workers' militia groups had begun to form (these became the Red Guard), and at the same time women from the factories, led by Bolshevik medical students, had formed medical brigades. On October 25 these brigades were ordered to the Winter Palace to help the wounded, but in fact the storming of the palace was achieved with very little bloodshed on either side. ${ }^{102}$ Altogether 200 members of first-aid detachments, almost all of them women, were sent to the Winter Palace and Nevskii Prospect area. ${ }^{103}$ Rodionova and her brigade from the Vasileostrovskii trampark were given the task of checking Red Guard posts and maintaining tram movements throughout the night of the 25-26th. ${ }^{104}$ T. I. Graf, a Bolshevik from a factory which produced medical supplies for the war, helped organise a medical brigade which operated in the Pulkov area amongst Red Guards defending the city from Kerensky's forces. ${ }^{105}$ Women also took an active military part in the armed uprising. The Vyborg-district Red Guard had produced a leaflet which called on both men and women to join up. ${ }^{106}$ On September 1, 4000 men and women workers belonging to the Kronstadt Red Guard were given intensive firing practice. ${ }^{107}$ The Petrograd City Conference of the Red Guard, which opened on November 3 , announced that women were also entering the ranks. ${ }^{108} \mathrm{~A}$ number of working women also took part in the storming of the

101 Kollontai, "Rabotnitsy zanimaite svoi revolyutsionnye posty!", in: Pravda, No 171 (28 October).

102 Tarasova, "Pod znamenem Bol'shevikov", loc. cit., pp. 137.

103 Bol'sheviki v period podgotovki i provedeniya Velikoi Oktyabr'skoi sotsialisticheskoi revolyutsii. Khronika sobytii v Petrograde, I: Aprel'-Oktyabr' 1917 g. (Leningrad, 1947), pp. $347-48$

104 Rodionova, "Semnadtsatyi god", loc. cit., pp. 91-92.

105 T. I. Graf et al., "Proletarskii Krasnyi Krest", in: Zhenshchiny goroda Lenina, pp. 106-12.

106 Listovki Petrogradskikh bol'shevikov, pp. 95-97.

107 Proletarskoe Delo, 1 September, cited in Bol'sheviki v period podgotovki, op. cit., p. 280.

108 Rabochii Put', No 42. 
Winter Palace. ${ }^{109}$ Altogether there were more armed Bolshevik women involved in the events of October 25 than there were women in the famous Women's Battalion which guarded the palace. ${ }^{110} \mathrm{~A}$ few women were also amongst the victims of the Petrograd uprising, including Slutskaya, who was killed by a shell splinter. ${ }^{111}$

The delayed Conference of Working Women finally began on November 5 , with a preliminary conference which was attended by 500 delegates, representing 80,000 working women. ${ }^{112}$ This response was ample justification for the months of work the Bolshevik women had undertaken amongst the working women of Petrograd. Yet, right up to the last moment, the conference was regarded with some hostility from within the party. On the day of the preliminary conference, Samoilova, who was noted for her wariness towards anything that "smelled of feminism", found herself having to refute charges that the conference would lead to separatism and division. ${ }^{113}$ The first item on the agenda of the preliminary conference was reports from the floor. The majority of the delegates stressed that they did not belong to any party, but they clearly sided with the Bolsheviks, and were ready to give every kind of support to the new Bolshevik government. When Kollontai spoke on the current situation, her powerful speech in support of the Bolshevik Revolution was greeted with enthusiastic applause. ${ }^{114}$

The First Petrograd Conference of Working Women was officially convened a week later, on November 12. It was attended by the same 500 delegates. The main item for discussion on the first day of the conference

109 Karpetskaya, Rabotnitsy, p. 114.

110 Stites, The Women's Liberation Movement, p. 306. The Provisional Government's Women's Death Battalions had received frequent criticism in the Bolshevik press. According to Porter, Alexandra Kollontai, op. cit., p. 265. "The Bolshevik papers printed various articles protesting against the way these women had been manipulated to prolong the war, without questioning either their idealism or their capacity to fight." In my opinion this assessment attributes to the Bolsheviks a more radical approach to the problem of woman's role in society than is in fact evident from a study of the Bolshevik press in 1917. Although contributions to Pravda and Rabotnitsa on the Women's Battalions did not question woman's capacity to fight. they did, however, attack the concept of a military role for women. Bolshevik articles called on women to organise detachments to work in the countryside, or to launder soldiers' clothes instead of joining armed battalions. See, for example, L. Vorob'evskii, "Batal'ony smerti", in: Rabochii i Soldat. No 7 (30 July). One wonders what was the reaction amongst Bolshevik men to the participation of so many armed women in the October Revolution.

111 Gilyarova, "V boyakh pod Pulkovom", in: Zhenshchiny goroda Lenina, p. 105.

112 "Predvaritel'noe soveshchanie rabotnits-delegatok na konferentsiyu". in: Pravda, No 184 (9 November).

113 Samoilova, "Soveshchanie rabotnits i ego zadachi", ibid., No 181 ( 5 November).

114 "Predvaritel'noe soveshchanie", loc. cit. 
was the elections to the Constituent Assembly. The Bolshevik speakers were naturally unanimous in their call for support for the Bolshevik list in the elections, ${ }^{115}$ but their speeches revealed differences in their approach towards the women delegates. Nikolaeva stressed the danger that that the more backward working women might be tempted to vote for the feminist candidates.

But we, conscious women workers, know that we have no special women's interests, that there should be no special women's organisations. We are strong only when organised together in one fraternal proletarian family with all workers in the struggle for socialism. ${ }^{116}$

Kollontai, on the other hand, adopted a rather different tack. She did not seek to submerge the special needs of working women, but urged them to ensure that women workers had their own representatives in the Assembly.

True, we know our fate is very closely linked with the fate of the whole workers' movement, but there are nevertheless separate questions which most closely concern us, and on which we, the conscious women workers, must make our voices heard in the Constituent Assembly. ${ }^{117}$

The difference between these speeches may have seemed a subtle one, but it was the tip of substantial divergence, which was to become evident at the second session of the conference during discussion on the organizational question. For the moment, however, these differences were forgotten as Doroshevskaya from the League of Equal Rights rose to speak. Doroshevskaya argued that men cannot defend women's interests, and pointed out that on the Bolshevik electoral lists women were very poorly represented - "not even Madame Kollontai has been placed at the top". 118 In fact Kollontai was high on the list, fifth after Lenin, Zinoviev, Trotsky and Kamenev, but she was an exception. The only other woman among the top 18 candidates was Nikolaeva at No $12 .{ }^{119}$ But whatever Kollontai might have thought privately about the lack of female representation in the Bolshevik hierarchy, she and the whole conference were clearly united in the belief that the League of Equal Rights defended only the interests of bourgeois women, and that working women have more in common with working men than with the women of Doroshevskaya's class. ${ }^{120}$

\footnotetext{
115 "Pervaya konferentsiya rabotnits", ibid., No 189 (14 November).

116 Rabotnitsa, No 12 (8 December), p. 11.

117 Ibid., p. 12.

118 Ibid., No 13 (26 January 1918), p. 11.

119 Reference is to the list of candidates presented in Petrograd. The Bolshevik list in the Petrograd province did not contain a single woman. See Pravda, No 184.

120 Rabotnitsa, No 13, pp. 11-12.
} 
The second session of the conference, held on November 18, was devoted mainly to the organizational question. The debate began with a speech from Solin, who declared that the conference should not lead to the formation of separate women's organisations, but that its task was to draw women workers into general proletarian organisations. In the debate that followed, Kollontai pointed out the important role the conference had played in organising women workers and awakening their classconsciousness. No one, declared Kollontai, could say now that women workers were not taking part in the revolutionary movement. After the discussion Samoilova moved a resolution which began by acknowledging the weak organisation and backwardness of working women. The resolution welcomed the conference as the first step in the mass organisation of women workers, but it repeated Solin's claim that it should not lead to the formation of separate women's organisations. It was necessary to encourage women to join the party and the trade unions, and to this end meetings and lectures should be arranged, and leaflets and copies of Rabotnitsa distributed. ${ }^{121}$

Kollontai put forward three amendments to this resolution. First, the Initiative Group which had organised the conference should not be disbanded, but should join with the Rabotnitsa board to carry out organised agitational work. Second, city-party committees of the RSDRP(b) should set up local committees (komissii) for agitation amongst women workers. Third, a secretariat should be formed from the Rabotnitsa editorial board to provide information and instructions, and to distribute literature. This would strengthen ties between Rabotnitsa and working women throughout Russia. ${ }^{122}$ Kollontai's amendments were hotly rejected by Solin, Nikolaeva and Samoilova on the grounds that they were opposed to the spirit of the resolution, and would be regarded in the localities as calling for the formation of separate women's organisations. When the conference voted in support of the amendments, Samoilova withdrew her resolution and Nikolaeva refused to continue chairing the conference. After a heated debate a special committee of five delegates was elected to try to produce an acceptable amended resolution, and Nikolaeva took the chair again at the unanimous request of the conference. ${ }^{123}$

A rather different view of events was recorded by Samoilova, who discussed the disagreements, but did not mention that Kollontai's amendments were supported by the majority of the conference. Samoilova wrote

121 "Konferentsiya rabotnits", in: Izvestiya, 23 November.

122 Kollontai, "K konferentsii rabotnits", Pravda, No 199 (25 November).

123 "Konferentsiya rabotnits", loc. cit. 
that a third position was held by Stal', who called for the setting up of special bureaux to conduct organizational work amongst women. According to Samoilova, not a single hand was raised in support of Stal"s proposal. The final compromise resolution included most of the original resolution plus substantial additions from Kollontai's amendments, though worded in a way that was presumably more acceptable to the movers of the resolution. Thus, the principle of the continuation of the work of the Initiative Group, and the formation of a secretariat from the Rabotnitsa board were accepted. The sticking point came with Kollontai's demand that city parties should form local committees for agitation and propaganda amongst women workers. This was reduced to the demand that all factory and party collectives in Petrograd and in the provinces should devote the greatest possible attention to work amongst the female proletariat, with the actual form of the work to be dictated by local conditions. The conference resolution also called for the convocation of an All-Russian Congress of Women Workers. ${ }^{124}$

In this way some sort of compromise was reached, which probably satisfied no one. It certainly did not satisfy Stal', who wrote in an open letter in Pravda that the revolutionary solidarity of the conference had been ruined by the disagreement on the organisational question, ${ }^{125}$ a view rejected by Samoilova, who refuted Stal"s suggestion that there had been a serious schism. ${ }^{126}$ according to Stal', a very small number of delegates declared their disagreement with Kollontai's proposal to organise agitation committees. Why, asked Stal', if they do not accept the need for special agitation amongst women workers, did they call this conference? Fear of "feminism", wrote Stal', was responsible for the poor level of organisation amongst the female proletariat of Petrograd up until now. Stal' complained that the bureau set up by the Petrograd Committee shortly after the February Revolution was never able to carry out its work because there were women party members who disagreed with the principle of the bureau. Stal' declared that agitational groups were not the same thing at all as "women's organisations", and she called for support for Kollontai's amendments. 127

Thus after nine months of intensive work amongst women the party as a whole and even the women activists themselves were still debating precisely those questions which had divided them in March, when the

\footnotetext{
124 Samoilova, "Konferentsiya rabotnits i organizatsionnaya rabota", in: Pravda, No 200 (26 November).

125 Stal', “Rabotnitsy - organizuites"?", ibid., No 198 (24 November).

126 Samoilova, "Konferentsiya rabotnits", loc. cit.

127 Stal', "Rabotnitsy - organizuites'!", loc. cit.
} 
problem of work amongst women had first been raised - that is what method or approach, and what extent, if any, of separate organisation, was acceptable to a Marxist party.

\section{Conclusion}

At first sight it might seem that little change occurred during 1917 in the Bolsheviks' attitude towards work amongst women. If the wording of Slutskaya's proposals, made in March, is compared with the wording of the resolution passed by the November conference, the impression given is that the intervening months of revolutionary activity had had no effect on party policy on this question. Slutskaya had stressed that "women workers will in general organise themselves in the workers' political and trade-union organisations". ${ }^{128}$ The conference resolution called on women "in close ranks to enter our general proletarian organisations, to enter the Bolshevik Party, the unions, the Soviets and the factory committees". ${ }^{129}$ However, the appearance of continuity and clarity of tactics is to some extent illusory.

Until March 1917 party policy had been that women should not be treated as a special case, and no special approach had been developed towards them, apart from the brief publication of Rabotnitsa in 1914. But in March the acceptance of Slutskaya's proposals was the first step on the path of divergence between theory and practice. It created the paradox that while stressing that women did not have special interests, and that existing organisations were perfectly adequate for their needs, the party was simultaneously agreeing to form a special women's bureau to conduct special work amongst women. By November this paradox had assumed even greater proportions. The Bolsheviks had been pushed to the extent of actually convening a separate women's conference in order to try to persuade working women that they had no separate interests, apart from those of working men. To add to this confusion and ambiguity, at the conference one of the party's leading figures, Kollontai, stood up and said that working women must be elected to the Constituent Assembly for the very reason that there do in fact exist "separate questions which most closely concern us, and on which we [.. .] must make our voices heard". ${ }^{130}$

While continuing to hold officially the same policy of opposition to any form of separate organisation, the party had been forced in practice to modify its tactics. For the first time in Russia, the revolutionary parties were faced with the challenge of a working class which had the opportunity

128 See above, p. 134.

129 Samoilova, "Konferentsiya rabotnits".

130 See above, p. 155. 
of exerting political power - and which had shown it was prepared to act. As we have seen, in 1917 one third of the Petrograd workforce consisted of women, women had been instrumental in the events of February, and women as well as men had obtained the vote after the February Revolution. During 1917 the Bolsheviks were made more aware than ever before of the significance of the female proletariat. This realization was forced upon the Bolsheviks from two opposite directions. The war and its political and economic consequences had produced in a growing minority of women an awareness of their economic importance, and a demand for greater social and political power. These were the "advanced" women who attended Rabotnitsa meetings, organised themselves in trade unions and joined the party. These women were able to prove that work amongst women could be carried out successfully, and that it could furnish valuable support for the Bolsheviks. At the other end of the scale the Bolsheviks were faced with the fact that the majority of women who had participated in the February uprising had done so not with any conscious political aim, but out of sheer desperation. Women, traditionally the most politically backward section of the population, now had the vote. Could the Bolsheviks rely on these women for support? The problem was made more pressing by the evident successes of the bourgeois-feminist movement. Thus, paradoxically, the activist Bolshevik women continually stressed the backwardness of the woman worker in their efforts to prod the party into conducting special work amongst women. ${ }^{131}$

It is true that by the end of the year the majority of the party did not accept Kollontai's radical approach to the woman question. But her persistent struggle within the party to gain acceptance of her views, and the clear organisational and agitational successes she had won amongst the

131 B. Farnsworth, Aleksandra Kollontai. Socialism, Feminism, and the Bolshevik Revolution (Stanford, 1980), p. 88, also discusses the reasons for the new approach. In common with Farnsworth I hold the opinion that Bobroff, "The Bolsheviks and Working Women", loc. cit., p. 541, underestimates the political backwardness of the masses of working women, stressing only the "tremendous growth" in their militancy. On the other hand, Farnsworth's assessment that the Bolsheviks still had a "negative estimate of the "baba", and that what they "did come to realize in the course of 1917 was the potential of the Rabotnitsa group, particularly Kollontai, to organize working-class women", does not fully explain the new developments. Kollontai had been trying for over a decade to persuade Russian Marxists of the need to devote special efforts to work amongst women. The vital new factor was that she and the Rabotnitsa group were no longer working in a vacuum. The war and the February Revolution had aroused the working women and, for the first time, they enjoyed full political rights. True, the Bolsheviks still feared the backwardness of the "baba", but there was a significant minority of politically conscious women workers, who attended Rabotnitsa meetings in their hundreds, and who were the living proof that the "baba" was undergoing a significant transformation. 
soldatki and laundresses, and as a leading figure in the Rabotnitsa group and the prime mover of the November conference, had an indisputable effect on the party and its attitude to work amongst women. The development of Samoilova's attitude to this question, as described by Kollontai herself, was probably typical of the experience of a number of Bolshevik women who came under Kollontai's influence at this time. As we have already noted, Samoilova was in early 1917 an ardent opponent of anything that "smacked of feminism", but by the summer the practicalities of work on Rabotnitsa had led her to form a special school of women agitators, while in theory she was still opposed to any sort of separate organisation. ${ }^{132}$ According to Kollontai, Samoilova reacted to the idea of a women's conference with her usual wariness, but she soon came to accept the necessity for it, and the success of the conference turned her into one of its most zealous defenders.

But if from late 1917 Comrade Samoilova became an ardent defender of non-party conferences of working women, she nevertheless continued to deny the necessity for a separate organisational apparatus in the party for the constant direction of working women. It was only in the spring of 1918 , once again as the result of experience and practice, that Comrade Samoilova came to the conclusion that separate work amongst women was necessary. ${ }^{133}$

1917 was thus a crucial period in the development of the attitude of the Bolshevik Party towards work amongst women. During the revolutionary year, while theoretically still opposed to special work amongst women, the party in practice allowed in the Rabotnitsa editorial board the creation of a special women's section, which actively developed support for the Bolsheviks amongst the female masses of Petrograd. The successes the Rabotnitsa women achieved amongst working women were often in spite of Bolshevik party policy, rather than because of it. Nevertheless, 1917 provided the soil in which some of Kollontai's ideas on the woman question could take root and flourish. Their early fruit was support for the Bolshevik Revolution amongst broad sections of the female proletariat, early Bolshevik legislation on maternity protection and, in 1919, the formation of the zhenotdely.

133 Kollontai, "Tvorcheskoe v rabote t. Samoilovoi", loc. cit., p. 10. 